\title{
Tingkat Kesehatan Bank Berdasarkan Analisis RGEC Pada Bank BNI 46
}

\author{
Pupu Sopini \\ Fakultas Ekonomi Universitas Batanghari \\ pupusopini08@gmail.com
}

\begin{abstract}
This research aims to know the level of health of Bank BNI 46 using RGEC (Risk Profile, Good Corporate Governance, Earning, Capital). Assessment of the health of the bank rate is used to determine whether the bank is in a very healthy condition, healthy, reasonably healthy, less healthy, or unhealthy. A healthy bank is a bank that is able to keep and maintain the trust of the community, can perform the function of intermediary, can help smooth the payment traffic and can be used by the Government in implementing the various policies relating to, especially monetary policy. This type of research uses descriptive analysis methods with quantitative approach that aims to describe systematically and factual about the facts as well as the relationships between variables are investigated by means of collecting data, processing menginterprestasikan, analyze, and secondary data from the financial statements of Bank BNI 46. The results showed that the Risk profiles of the components of the Non Performing Loan (NPL) average value below $2 \%$ which means that bank BNI 46 are at a very healthy state, means the bank can control the risk of going bad credit happens. As for the components of the Loan to Deposit Ratio (LDR) bank BNI 46 from 2012-2016 experience fluctuating growth declines and are in the position well enough. This suggests that the ability of the lower liquidity of bank BNI 46. The results of the rating component of Good Corporate Governance $(G C G)$ is at rank 2 which means in a State of healthy, so the bank has good corporate governance. Assessment of Earnings/earning ratios seen from the value of the Return on Equity (ROE) above 15\% very good circumstances, it means that the bank maintains consistent gains its profits. NET Interest Margin (NIM)) bank BNI 46 in 2007-2016 have a rating above 3\% NIM means the bank is in very good condition. Value-based capital components Capital Adequacy Ratio (CAR) have a rating above $11 \%$ which means it is in very good condition. This means bank BNI 46 have capital adequacy to fulfill obligations that are owned, both in its business activities as well as funding to cover the risk in the future.
\end{abstract}

Keywords: bank, methods of health level RGEC

\section{PENDAHULUAN}

Lembaga keuangan Bank, selain memiliki fungsi menghimpun dan menyalurkan dana, bank juga berfungsi untuk memberikan pelayanan kepada masyarakat yang berupa penawaran jasa-jasa perbankan seperti jasa pengiriman uang, penitipan barang berharga, dan lain sebagainya serta memberikan rasa aman dan nyaman kepada masyarakat yang menggunakan jasanya. Bank Indonesia telah menetapkan aturan tentang kesehatan bank agar perbankan diharapkan selalu dalam kondisi sehat, sehingga tidak akan merugikan masyarakat yang berkepentingan

Tingkat Kesehatan Bank Berdasarkan Analisis RGEC Pada Bank BNI 46 
dengan perbankan. Dalam mencapai kesehatan perbankan tersebut, bank-bank yang ada di Indonesia akan diawasi oleh Otoritas Jasa Keuangan (OJK) sebagai pengatur dan pengawas terhadap kegiatan jasa keuangan di sektor perbankan yang sebelumnya dijalankan oleh Bank Indonesia. (Adisetiawan, 2013)

Penilaian tingkat kesehatan bank digunakan untuk mengetahui apakah bank tersebut dalam kondisi yang sangat sehat, sehat, cukup sehat, kurang sehat, atau tidak sehat. Bank yang sehat adalah bank yang dapat menjaga dan memelihara kepercayaan masyarakat, dapat menjalankan fungsi intermediasi, dapat membantu kelancaran lalu lintas pembayaran serta dapat digunakan oleh pemerintah dalam melaksanakan berbagai kebijakannya, terutama kebijakan moneter. Bank yang tidak sehat, bukan hanya membahayakan perbankan itu saja, akan tetapi pihak lain yang terkait, yaitu pemilik dan pengelola bank, masyarakat pengguna jasa bank dan Pemerintah (Bank Indonesia) selaku pengawas dan pembina perbankan. (Adisetiawan, 2013)

Perubahan sistem penilaian tingkat kesehatan bank umum dari metode CAMELS menjadi metode RGEC disebabkan krisis keuangan global yang terjadi beberapa tahun terakhir memberi pelajaran berharga bahwa inovasi dalam produk, jasa dan aktivitas perbankan yang tidak diimbangi dengan penerapan Manajemen Risiko yang memadai dapat menimbulkan berbagai permasalahan mendasar pada bank maupun terhadap sistem keuangan secara keseluruhan. Selain itu terjadinya kegagalan strategi dan praktek curang dari manajemen puncak yang berlangsung tanpa terdeteksi dan menyebabkan pentingnya penerapan tata kelola perusahaan yang baik (GCG). Pengalaman dari krisis keuangan global tersebut mendorong perlunya peningkatan efektivitas penerapan Manajemen Risiko dan GCG. Tujuannya adalah agar bank mampu mengidentifikasi permasalahan secara lebih dini, melakukan tindak lanjut perbaikan yang sesuai dan lebih cepat, serta menerapkan GCG dan Manajemen Risiko yang lebih baik sehingga bank lebih tahan dalam menghadapi krisis. Sejalan dengan perkembangan tersebut di atas, Bank Indonesia menyempurnakan metode penilaian tingkat kesehatan bank umum.

Peneliti mengambil objek penelitian pada salah satu bank BUMN, yaitu PT. Bank Negara Indonesia (Persero) Tbk (BNI 46). BNI 46 tercatat sebagai bank nasional terbesar ke-4 di Indonesia, dilihat dari total asset, total kredit maupun total dana pihak ketiga. Di akhir tahun 2016, jumlah asset yang dimiliki BNI 46 tercatat sebesar Rp.603 truliun dan jumlah karyawan sebanyak 24.272 orang. Pada Desember ,2016 total ekuitas tercatat sebesar Rp89,3 triliun atau meningkat 13,8\% dibandingkan dengan Desember 2015. Peningkatan ini disebabkan tambahan laba bersih tahun 2016 yang mencerminkan kinerja BNI 46 yang semakin baik. (Adisetiawan, 2015)

Prinsip umum penilaian kesehatan bank berpedoman pada Surat Edaran Bank Indonesia No.13/24/DPNP tanggal 25 Oktober 2011 adalah : (a) berorientasi Risiko, penilaian tingkat kesehatan didasarkan pada risiko - risiko bank dan dampak yang ditimbulkan ada kinerja bank secara keseluruhan. Hal ini dilakukan dengan cara mengidentifikasi faktor internal maupun eksternal dan dapat meningkatkan risikorisiko atau mempengaruhi kinerja keuangan bank; (b) proporsionalitas, penggunaan parameter/indikator dalam setiap faktor penilaian tingkat kesehatan bank dilakukan dengan memperhatikan karakteristik dan kompleksitas usaha bank; (c) materialitas 
dan Signifikasi, dalam memperhatikan materialitas/signifikasi faktor penilaian tingkat kesehatan bank yaitu Profil Risiko, GCG, Rentabilitas, dan Permodalan. Penentuan materialitas dan signifikansi didasarkan pada analisis yang didukung oleh data dan informasi yang memadahi tentang risiko dan kinerja keuangan bank; dan (d) komprehensif dan terstruktur, proses penilaian dilakukan secara menyeluruh dan sistemaatis serta difokuskan pada permasalahan utama bank. Analisis dilakukan secara terintregasi, yaitu dengan mempertimbangkan keterkaitan antara risiko dan faktor penilaian Tingkat Kesehatan Bank. (Adisetiawan, 2015)

Dalam Surat Edaran (SE) Bank Indonesia No/13/24/DPNP tanggal 25 Oktober 2011 tentang Penilaian Tingkat Kesehatan Bank Umum, penilaian terhadap faktor-faktor RGEC terdiri dari:

\section{A. Profil risiko (Risk profile)}

Dalam menilaii kualitas penerapan manajemen risiko perlu memperhatikan karakteristik dan kompleksitas usaha bank. Terdapat delapan jenis risiko yang digunakan bank dalam penialain Risk profile, yaitu risiko kredit, risiko pasar, risiko likuiditas, risiko operasional, risiko hukum, risiko stratejik, risiko kepatuhan dan risiko reputasi. Dalam penelitian ini peneliti mengukur faktor risk profile dengan menggunakan 2 indikator yaitu faktor risiko kredit dengan menggunakan rumus NPL dan risiko likuiditas dengan rumus LDR.

a. Risiko Kredit, yaitu risiko kerugian yang diderita bank karena debitur tidak melunasi kembali kewajibannya kepada pihak bank (Ali, 2006 : 199). Risiko kredit dihitung dengan menggunakan rasio Non Performing Loan. Kredit bermasalah diakibatkan oleh ketidak lancaran pembayaran pokok pinjaman dan bunga yang secara langsung dapat menurunkan kinerja bank dan menyebabkan bank tidak efisien. Rasio Non Performing Loan (NPL) berdasarkan Sumber Lampiran SE BI No. 13/24/DPNP/2011 dapat dirumuskan sebagai berikut $: \mathrm{NPL}=\frac{\text { Kredit Bermasalah }}{\text { Total Kredit }} \mathrm{x} 100 \%$

b. Risiko Likuiditas, yaitu melihat kemampuan bank dalam memenuhi kewajiban jangka pendek maupun kewajiban yang sudah jatuh tempo. Indikator yang digunakan untuk mengukur risiko likuiditas dengan menggunakan pengukuran Loan to Deposit Ratio (LDR). Semakin tinggi LDR menunjukkan bahwa semakin rendah likuiditas bank karena terlalu besar jumlah dana masyarakat yang dialokasikan ke kredit (Irmayanto, 2009 : 90). Berdasarkan Sumber Lampiran SE BI No. 13/24/DPNP/2011 rasio Loan to Deposit Ratio (LDR) dapat dirumuskan sebagai berikut : LDR $=\frac{\text { Total Kredit }}{\text { Dana Pihak Ketiga }} \times 100$

c. Risiko Pasar, yaitu risikp pada posisi neraca dan rekening administrative termasuk transaksi derivative, akibat perubahan dari kondisi pasar, termasuk risiko perubahan harga option. Risiko pasar merupakan suatu risiko yang timbul karena menurunnya nilai suatu investas karena pergerakan pada faktorfaktor pasar. Risiko ini merupakan risiko gabungan yang terbentuk akibat perubahan suku bunga, perubahan nilai tukar, serta hal-hal lain yang menentukan harga pasar saham, maupun ekuitas. 
d. Risiko Operasional, yaitu risiko kerugian yang diakibatkan oleh kegagalan atau tidak memadainya proses internal, manusia dan sistem, atau sebagai akibat dari kejadian eksternal.

e. Risiko Hukum, yaitu risiko dari ketidakpastian tindakan atau tuntutan atau ketidakpastian dari pelaksanaan atau interprestasi dari kontrak, hukum atau peraturan.

f. Risiko Stratejik, yaitu risiko yang disebabkan oleh adanya penetapan dan pelaksanaan strategi bank yang tidak tepat, pengambilan keputusan bisnis yang tidak tepat atau kurang responsifnya bank terhadap perubahan eksternal.

g. Risiko Kepatuhan, yaitu risiko yang disebabkan oleh ketidakpastian suatu bank untuk melaksanakan perundang-undangan dan ketentuan lain yang berlaku

h. Risiko Reputasi, yaitu risiko akibat menurunnya tingkat kepercayaan stakeholder yang bersumber dari persepsi negative terhadap bank.

\section{B. Good Corporate Governance (GCG)}

Good Corporate governance adalah konsep untuk peningkatan kinerja perusahaan melalui supervise atau monitoring kinerja manajemen dan menjamin akuntabilitas manajemen terhadap stakeholder dengan mendasarkan pada kerangka peraturan. Berdasarkan SE BI No. 15/15/DPNP Tahun 2013 bank diharuskan melakukan penilaian sendiri (self assessment) terhadap pelaksanaan GCG. Nilai komposit GCG membantu peneliti dalam melihat keadaan GCG suatu bank. Penilaian terhadap faktor GCG dalam pendekatan RGEC didasarkan ke dalam tiga aspek utama yaitu : (a) Governance structure mencakup pelaksanaan tugas dan tanggung jawab Dewan Komisaris dan Dewan Direksi serta kelengkapan dan pelaksanaan tugas komite.; (b) Governance process mencakup fungsi kepatuhan bank, penanganan benturan kepentingan, penerapan fungsi audit intern dan ekstern, penerapan manajemen risiko termasuk sistem pengendalian intern, penyediaan dana kepada pihak terkait dan dana besar, serta rencana strategis bank; dan (c) Governance output mencakup transaparansi kondisi keuangan dan non keuangan, laporan pelaksanaan GCG yang memenuhi prinsip Transparancy, Accountability, Responsibility, Indepedency, dan Fairness (TARIF)".

\section{Rentabilitas (Earnings)}

Berdasarkan Surat Edaran Bank Indonesia Nomor 13/24/DPNP tanggal 25 oktober 2011, penilaian terhadap faktor rentabilitas diukur dengan beberapa parameter/indikator. Penilaian terhadap faktor earnings didasarkan pada dua rasio yaitu:

a. Return on Equity (ROE), Rasio ini digunakan untuk mengindikasikan kemampuan bank dalam menghasilkan laba dengan menggunakan ekuitasnya. Kenaikan dalam rasio ini berarti terjadi kenaikan laba bersih dari bank yang bersangkutan dan selanjutnya kenaikan tersebut akan menyebabkan kenaikan harga saham bank. Dendawijaya (2009:119). ROE dapat dirumuskan sebagai berikut : $\mathrm{ROE}=\frac{\text { Laba Bersih }}{\text { Modal Sendiri }} \times 100 \%$ 
b. Net Interest Margin (NIM), Rasio Net Interest Margin (NIM) menurut Frianto Pandia (2012:71) adalah Rasio yang digunakan untuk mengukur kemampuan manajemen bank dalam mengelola aktiva produktifnya untuk menghasilkan pendapatan bunga bersih. NIM dapat di rumuskan sebagai berikut : $\mathrm{NIM}=\frac{\text { Pendapatan Bunga Bersi h }}{\text { Rata-rata Aset Produktif }} \times 100 \%$

c. Penilaian Permodalan (Capital), Rasio kecukupan modal dihitung dengan rasio Capital Adequacy Ratio (CAR). CAR adalah rasio yang memperlihatkan seberapa jauh seluruh aktiva bank yang mengandung risiko (kredit, penyertaan, surat berharga, tagihan pada bank lain) ikut dibiayai dari dana modal sendiri bank, disamping memperoleh dana-dana dari sumber-sumber diluar bank, seperti dana masyarakat, pinjaman (hutang), dan lain-lain (Dendawiyaja, 2006). Berdasarkan Sumber Lampiran SE BI No. 13/24/DPNP/2011 rumus rasio CAR sebagai berikut : $\mathrm{CAR}=\frac{\text { Modal Bank }}{\text { ATMR }} \times 100 \%$

\section{METODE}

Jenis penelitian ini menggunakan metode analisis deskriptif dengan pendekatan kuantitaf dengan mengolah laporan keuangan berdasarkan dengan rasio Profil Risiko (Risk profile), Good Corporate Governance (GCG), Rentabilitas (Earnings) dan Permodalan (Capital) atau disingkat menjadi metode RGEC. Metode analisis deskriptif dengan pendekatan kuantitatif merupakan metode yang bertujuan menggambarkan secara sistematis dan faktual tentang fakta-fakta serta hubungan antar variabel yang diselidiki dengan cara mengumpulkan data, mengolah, menganalisis, dan menginterprestasikan data. Jenis dan sumber data yang digunakan adalah data sekunder yang bersumber dari summery report pada bank BNI 46 tahun 2007-2016 yang dipublikasikan pada situs Indonesia Stock Exchange (www.idx.co.id). Pengklasifikasian rentang penilaian seiap variabel yang diteliti menggunakan metode RGEC adalah sebagai berikut :

Risk Profil

a. Risiko Kredit

Tabel 1

Matriks Kriteria Penetapan Peringkat Non Performing Loan (NPL)

\begin{tabular}{lll}
\hline Peringkat & Keterangan & Kriteria \\
\hline 1 & Sangat Sehat & $0 \%<\mathrm{NPL}<2 \%$ \\
2 & Sehat & $2 \%<\mathrm{NPL}<5 \%$ \\
3 & Cukup Sehat & $5 \%<\mathrm{NPL}<8 \%$ \\
4 & Kurang Sehat & $8 \%<\mathrm{NPL}<11 \%$ \\
5 & Tidak Sehat & NPL $>11 \%$ \\
\hline
\end{tabular}

Sumber: Kodifikasi Penilaian Tingkat Kesehatan Bank Tahun 2012

b. Likuiditas 
Tabel 2

Matriks Kriteria Penetapan Peringkat Loan to Deposit Ratio (LDR)

\begin{tabular}{lll}
\hline Peringkat & Keterangan & Kriteria \\
\hline 1 & Sangat Sehat & $50 \%<\mathrm{LDR}<75 \%$ \\
2 & Sehat & $75 \%<\mathrm{LDR} \leq 85 \%$ \\
3 & Cukup Sehat & $85 \%<\mathrm{LDR}<100 \%$ \\
4 & Kurang Sehat & $100 \%<\mathrm{LDR} \leq 120 \%$ \\
5 & Tidak Sehat & LDR $>120 \%$ \\
\hline
\end{tabular}

Sumber: Kodifikasi Penilaian Tingkat Kesehatan Bank Tahun 2012

Good Corporate Governance

Tabel 3

Matriks Kriteria Penetapan Peringkat Good Corporate Governance

\begin{tabular}{lll}
\hline Peringkat & Keterangan & Kriteria \\
\hline 1 & Sangat Sehat & Memiliki NK $<1,5$ \\
2 & Sehat & Memiliki NK $1,5 \leq$ NK $<2,5$ \\
3 & Cukup Sehat & Memiliki NK $2,5 \leq \mathrm{NK}<3,5$ \\
4 & Kurang Sehat & Memiliki NK $3,5 \leq \mathrm{NK}<4,5$ \\
5 & Tidak Sehat & Memiliki NK $4,5 \leq \mathrm{NK}<5$ \\
\hline
\end{tabular}

Sumber: Surat Edaran Bank Indonesia No. 9/12/DPNP/2007

Rentabilitas (Earnings)

a. Return On Equity

Tabel 4

Matriks Kriteria Penetapan Peringkat Return On Equity (ROE)

\begin{tabular}{lll}
\hline Peringkat & Keterangan & Kriteria \\
\hline 1 & Sangat Sehat & ROE $>15 \%$ \\
2 & Sehat & $12,5 \%<\mathrm{ROE} \leq 15 \%$ \\
3 & Cukup Sehat & $5 \%<\mathrm{ROE} \leq 12,5 \%$ \\
4 & Kurang Sehat & $0 \%<\mathrm{ROE} \leq 5 \%$ \\
5 & Tidak Sehat & $\mathrm{ROE} \leq 0 \%$ \\
\hline
\end{tabular}

Sumber: SE BI No. 6/23/DPNP tahun 2004

b. Net Interest Margin

Tabel 5

Matriks Kriteria Penetapan Peringkat Net Interest Margin (NIM)

\begin{tabular}{lll}
\hline Peringkat & Keterangan & Kriteria \\
\hline 1 & Sangat Sehat & $3 \%>\mathrm{NIM}$ \\
2 & Sehat & $2 \%<\mathrm{NIM} \leq 3 \%$ \\
3 & Cukup Sehat & $1,5 \%<\mathrm{NIM} \leq 2 \%$ \\
4 & Kurang Sehat & $1 \%<\mathrm{NIM} \leq 1,5 \%$ \\
5 & Tidak Sehat & NIM $\leq 1 \%$ \\
\hline
\end{tabular}


Sumber: Kodifikasi Penilaian Tingkat Kesehatan Bank Tahun 2012

Penilaian Permodalan (Capital)

Tabel 6

Matriks Kriteria Penetapan Peringkat Capital Adequacy Ratio (CAR)

\begin{tabular}{lll}
\hline Peringkat & Keterangan & Kriteria \\
\hline 1 & Sangat Sehat & CAR $\geq 11 \%$ \\
2 & Sehat & $9,5 \% \leq \mathrm{CAR}<11 \%$ \\
3 & Cukup Sehat & $8 \% \leq \mathrm{CAR}<9,5 \%$ \\
4 & Kurang Sehat & $6,5 \% \leq \mathrm{CAR}<8 \%$ \\
5 & Tidak Sehat & CAR $<6,5 \%$ \\
\hline
\end{tabular}

Sumber: Kodifikasi Penilaian Tingkat Kesehatan Bank Tahun 2012

\section{HASIL}

Penilaian tingkat kesehatan bank digunakan untuk mengetahui apakah bank tersebut dalam kondisi yang sangat sehat, sehat, cukup sehat, kurang sehat, atau tidak sehat. Bank yang sehat adalah bank yang dapat menjaga dan memelihara kepercayaan masyarakat, dapat menjalankan fungsi intermediasi, dapat membantu kelancaran lalu lintas pembayaran serta dapat digunakan oleh pemerintah dalam melaksanakan berbagai kebijakannya, terutama kebijakan moneter. Bank yang tidak sehat, bukan hanya membahayakan perbankan itu saja, akan tetapi pihak lain yang terkait, yaitu pemilik dan pengelola bank, masyarakat pengguna jasa bank dan Pemerintah (Bank Indonesia) selaku pengawas dan pembina perbankan.

\section{Risk Profile (Profil Risiko)}

a. Risiko Kredit

Pada penelitian ini untuk mengetahui risiko kredit dihitung menggunakan rasio Non Performing Loan (NPL). Berikut jumlah dan bobot peringkat komposit Non Performing Loan (NPL) pada bank BNI 46 tahun 2007-2016 dapat dilihat melalui tabel 7 berikut :

\section{Tabel 7}

Jumlah dan Bobot Peringkat Komposit Komponen Non Performing Loan (NPL) BNI 46 Periode 2007-2016

\begin{tabular}{llll}
\hline Tahun & NPL $\mathbf{( \% )}$ & Peringkat & Kriteria \\
\hline 2007 & 4 & 1 & Sehat \\
2008 & 1,7 & 1 & Sangat Sehat \\
2009 & 0,8 & 1 & Sangat Sehat \\
2010 & 1,1 & 1 & Sangat Sehat \\
2011 & 0,5 & 1 & Sangat Sehat \\
2012 & 0,7 & 1 & Sangat Sehat \\
2013 & 0,5 & 1 & Sangat Sehat \\
2014 & 0,4 & 1 & Sangat Sehat \\
2015 & 0,9 & 1 & Sangat Sehat \\
2016 & 0,4 & 1 & Sangat Sehat \\
\hline
\end{tabular}

Sumber : Data yang sudah diolah 
Berdasarkan dari hasil penilaian bobot komponen Non Performing Loan (NPL) bahwa bank BNI 46 berada pada keadaan sangat sehat. Bank yang memiliki kriteria sangat sehat berarti dapat mengendalikan risiko akan kredit macet yang terjadi. Nilai rasio NPL yang rendah menunjukkan rendahnya kredit yang dikategorikan tidak lancar atau macet. Nilai rasio semakin menurun dari tahun ke tahun dapat mengindikasikan kelangsungan keuangan bank yang baik.

\section{Risiko Likuiditas}

Rasio keuangan ini menerangkan bahwa Loan to Deposit Ratio (LDR) digunakan untuk mengukur perbandingan jumlah kredit yang diberikan bank dengan dana yang diterima oleh bank. Berikut jumlah dan bobot peringkat komposit Loan to Deposit Ratio (LDR) pada bank BNI 46 tahun 2007-2016 dapat dilihat melalui tabel 8 berikut:

\section{Tabel 8}

Jumlah dan Bobot Peringkat Komposit Komponen Loan to Deposit Ratio (LDR) BNI 46 Periode 2007-2016

\begin{tabular}{llll}
\hline Tahun & LDR $(\%)$ & Peringkat & Kriteria \\
\hline 2007 & 60,6 & 1 & Sangat Sehat \\
2008 & 68,6 & 1 & Sangat Sehat \\
2009 & 64,1 & 1 & Sangat Sehat \\
2010 & 70,2 & 1 & Sangat Sehat \\
2011 & 70,4 & 1 & Sangat Sehat \\
2012 & 77,5 & 2 & Sehat \\
2013 & 85,3 & 3 & Cukup Sehat \\
2014 & 87,7 & 3 & Cukup Sehat \\
2015 & 87,9 & 3 & Cukup Sehat \\
2016 & 90,4 & 3 & Cukup Sehat \\
\hline
\end{tabular}

Sumber : Data yang sudah diolah

Berdasarkan dari hasil penilaian bobot komponen Loan to Deposit Ratio (LDR) bahwa bank BNI 46 pada periode 2007-2016 mengalami penurunan dan berada diposisi cukup sehat, yang pada tahun-tahun sebelumnya dalam keadaan sangat sehat. Hal ini menunjukkan bahwa semakin rendah kemampuan likuiditas bank BNI 46, karena terlalu besar jumlah dana masyarakat yang dialokasikan ke kredit.

\section{Good Corporate Governance (GCG)}

Good Corporate Governance adalah konsep untuk peningkatan kinerja perusahaan melalui supervise atau monitoring kinerja manajemen dan menjamin akuntabilitas manajemen terhadap stakeholder dengan mendasarkan pada kerangka peraturan. Berikut peringkat Good Corporate Governance (GCG) pada bank BNI 46 periode 2007-2016 dapat dilihat melalui tabel 9 berikut : 


\section{Tabel 9}

\section{Peringkat Komposit Komponen Good Corporate Governance (GCG) BNI 46} Periode 2007-2016

\begin{tabular}{lll}
\hline Tahun & Peringkat & Keterangan \\
\hline 2007 & 1 & Sangat Sehat \\
2008 & 2 & Sehat \\
2009 & 1 & Sangat Sehat \\
2010 & 1 & Sangat Sehat \\
2011 & 1 & Sangat Sehat \\
2012 & 1 & Sangat Sehat \\
2013 & 2 & Sehat \\
2014 & 2 & Sehat \\
2015 & 2 & Sehat \\
2016 & 2 & Sehat \\
\hline
\end{tabular}

Sumber : Data yang sudah diolah

Berdasarkan dari hasil penilaian peringkat komponen Good Corporate Governance (GCG) pada penyajian data dapat dilihat bahwa GCG bank BNI 46 pada periode 2007-2016 mengalami keadaan sehat, sehingga bank tersebut memiliki tata kelola perusahaan yang baik.

\section{Earnings (Rentabilitas)}

Rasio rentabilitas adalah alat untuk menganalisis atau mengukur tingkat efisiensi usaha dan profitabilitas yang dicapai oleh bank yang bersangkutan. Penilaian terhadap faktor earnings didasarkan pada dua rasio yaitu:

a. Return On Equity (ROE)

Return on Equity (ROE) digunakan untuk mengindikasikan kemampuan bank dalam menghasilkan laba dengan menggunakan ekuitasnya. Berikut jumlah dan bobot peringkat ROE pada bank BNI 46 dapat dilihat melalui tabel 10 berikut :

\section{Tabel 10}

Jumlah dan Bobot Peringkat Komposit Komponen Return on Equity (ROE) BNI 46 Periode 2007-2016

\begin{tabular}{llll}
\hline Tahun & ROE $\mathbf{( \% )}$ & Peringkat & Kriteria \\
\hline 2007 & 8 & 2 & Sehat \\
2008 & 9 & 2 & Sehat \\
2009 & 16,3 & 1 & Sangat Sehat \\
2010 & 24,7 & 1 & Sangat Sehat \\
2011 & 20,1 & 1 & Sangat Sehat \\
2012 & 19,9 & 1 & Sangat Sehat \\
2013 & 22,5 & 1 & Sangat Sehat \\
2014 & 23,6 & 1 & Sangat Sehat \\
2015 & 17,2 & 1 & Sangat Sehat \\
2016 & 15,5 & 1 & Sangat Sehat \\
\hline
\end{tabular}

Sumber : Data yang sudah diolah 
Berdasarkan dari hasil penilaian bobot komponen Return on Equity (ROE) bahwa bank BNI 46 memiliki peringkat nilai Return on Equity (ROE) pada keadaan sangat baik. Rasio ROE yang terus meningkat menunjukkan bahwa bank konsisten mempertahankan perolehan labanya.

b. Net Interest Margin (NIM)

Net Interest Margin (NIM) merupakan rasio yang mengukur kemampuan bank dalam menghasilkan pendapatan bunga bersih atas pengolahan besar aktiva produktif. Berikut jumlah dan bobot peringkat Net Interest Margin (NIM) pada bank BNI 46 tahun 2007-2016 dapat dilihat melalui tabel 11 berikut :

Tabel 11

Jumlah dan Bobot Peringkat Komposit Komponen Net Interest Margin (NIM) BNI 46 Periode 2007-2016

\begin{tabular}{llll}
\hline Tahun & NIM $(\%)$ & Peringkat & Kriteria \\
\hline 2007 & 5 & 1 & Sangat Sehat \\
2008 & 6,3 & 1 & Sangat Sehat \\
2009 & 6 & 1 & Sangat Sehat \\
2010 & 5,8 & 1 & Sangat Sehat \\
2011 & 6 & 1 & Sangat Sehat \\
2012 & 5,9 & 1 & Sangat Sehat \\
2013 & 6,1 & 1 & Sangat Sehat \\
2014 & 6,2 & 1 & Sangat Sehat \\
2015 & 6,4 & 1 & Sangat Sehat \\
2016 & 6,2 & 1 & Sangat Sehat \\
\hline
\end{tabular}

Sumber : Data yang sudah diolah

Berdasarkan dari hasil penilaian bobot komponen Net Interest Margin (NIM) menunjukkan bahwa bank BNI 46 memiliki peringkat NIM sangat baik. Semakin besar rasio NIM, maka semakin meningkat pula pendapatan bunga atas aktiva produktif yang dikelola bank sehingga kemungkinan bank dalam kondisi bermasalah semakin kecil.

\section{Capital (Permodalan)}

Rasio kecukupan modal dihitung dengan rasio Capital Adequacy Ratio (CAR) yaitu rasio yang memperlihatkan seberapa jauh seluruh aktiva bank yang mengandung risiko (kredit, penyertaan, surat berharga, tagihan pada bank lain) yang dibiayai dari dana modal sendiri bank baik dari sumber-sumber di luar bank (dana masyarakat, pinjaman/utang). Berikut jumlah dan bobot peringkat Capital Adequacy Ratio (CAR) pada bank BNI 46 tahun 2007-2016 dapat dilihat melalui tabel 12 berikut : 


\section{Tabel 12}

\section{Jumlah dan Bobot Peringkat Komposit Komponen Capital Adequacy Ratio} (CAR) BNI 46 Periode 2007-2016

\begin{tabular}{llll}
\hline Tahun & CAR $(\boldsymbol{\%})$ & Peringkat & Kriteria \\
\hline 2007 & 15,7 & 1 & Sangat Sehat \\
2008 & 13,5 & 1 & Sangat Sehat \\
2009 & 13,8 & 1 & Sangat Sehat \\
2010 & 18,6 & 1 & Sangat Sehat \\
2011 & 17,6 & 1 & Sangat Sehat \\
2012 & 16,7 & 1 & Sangat Sehat \\
2013 & 15,1 & 1 & Sangat Sehat \\
2014 & 16,2 & 1 & Sangat Sehat \\
2015 & 19,5 & 1 & Sangat Sehat \\
2016 & 19,4 & 1 & Sangat Sehat \\
\hline
\end{tabular}

Sumber : Data yang sudah diolah

Berdasarkan dari hasil penilaian bobot komponen Capital Adequacy Ratio (CAR) bahwa bank BNI 46 memiliki peringkat CAR sangat baik. Semakin tingginya nilai CAR dapat dikatakan bahwa bank memiliki kecukupan modal untuk memenuhi kewajiban yang dimiliki, baik dalam mendanai kegiatan usahanya maupun untuk menutupi terjadinya risiko di masa yang akan datang yang dapat menyebabkan kerugian.

\section{SIMPULAN}

1. Risk Profile berdasarkan perhitungan nilai Non Performing Loan NPL pada bank BNI 46 berada pada keadaan sangat sehat, artinya Bank tersebut berada pada kriteria sangat sehat yaitu bank dapat mengendalikan risiko akan kredit macet yang terjadi. Sedangkan hasil perhitungan LDR Bank BNI 46 periode 2007-2016 mengalami penurunan dari kriteria sangat sehat menjadi cukup sehat, artinya semakin rendah kemampuan likuiditas Bank BNI 46 karena terlalu besar jumlah dana masyarakat yang dialokasikan ke kredit.

2. Komponen Good Corporate Governance (GCG) bank BNI 46 pada periode 2007-2016 dalam kriteria sehat, yang berarti bahwa bank tersebut memiliki tata kelola perusahaan yang baik.

3. Penilaian terhadap faktor Earnings didasarkan pada komponen Return on Equity (ROE), bank BNI 46 termasuk dalam kriteria sangat baik, artinya bank selalu konsisten mempertahankan perolehan labanya. Komponen Net Interest Margin (NIM) bank BNI 46 termasuk dalam kriteria sangat baik. Berarti semakin meningkat pendapatan bunga atas aktiva produktif yang dikelola bank sehingga kemungkinan bank dalam kondisi bermasalah semakin kecil.

4. Berdasarkan hasil penilaian komponen Capital Adequacy Ratio (CAR) pada bank BNI 46 periode 2007-2016, bank tersebut termasuk dalam kriteria sangat baik. Artinya bank memiliki kecukupan modal untuk memenuhi kewajiban yang dimiliki, baik dalam mendanai kegiatan usahanya maupun untuk menutupi terjadinya risiko di masa yang akan datang yang dapat menyebabkan kerugian. 


\section{DAFTAR PUSTAKA}

Adisetiawan, R., 2013, Kajian Persepsi Pemilik Usaha Kecil dan Menengah (UKM) Terhadap Laporan Keuangan, Jurnal Ilmiah Universitas Batanghari Jambi, 13(4), 162-173

Adisetiawan, R., 2015, Simultan Jangka Panjang Antara Fluktuasi Indeks Harga Saham, Tingkat Inflasi, Suku Bunga dan Kurs IDR/USD Terhadap Return Saham Reksadana di Indonesia, EKSIS: Jurnal Ilmiah Ekonomi dan Bisnis, 6(1), 5-17

Arikunto, Suharsimi. 2014. Prosedur Penelitian Suatu Pendekatan Praktik. Jakarta : Rineka Cipta.

Bank Indonesia. 2004. Peraturan Bank Indonesia No.6/10/PBI/2004. Perihal Penilaian Tingkat Kesehatan Bank Umum. Jakarta : Bank Indonesia. , 2004. Surat Edaran Bank Indonesia No. 6/23/DPNP Tanggal 31 Mei 2004. Perihal Penilaian Tingkat Kesehatan Bank Umum. Jakarta : Bank Indonesia.

-----------------, 2007. Surat Edaran Bank Indonesia No. 9/12/DPNP/2007 Perihal Pelaksanaan Good Corporate Governance bagi Bank Umum. Jakarta: Bank Indonesia.

, 2011. Peraturan Bank Indonesia Nomor : 13/1/PBI/2011 Perihal Penilian Tingkat Kesehatan Bank Umum. Jakarta: Bank Indonesia.

-----------------, 2011. Lampiran Surat Edaran Bank Indonesia No. 13/24/DPNP Perihal Penilaian Tingkat Kesehatan Bank Umum. Jakarta: Bank Indonesia. Indonesia.

Bank Negara Indonesia. 2007, 2008, 2009, 2010, 2011, 2012, 2013, 2014, 2015, 2016. Laporan Keuangan Bank Negara Indonesia. Jakarta: Bank Negara Indonesia.

Budisantoso, Totok dan Nuritomo. 2014. Bank dan Lembaga Keuangan Lain. Jakarta: Salemba Empat.

Dendawijaya, Lukman. 2005. Manajemen Perbankan. Jakarta : Penerbit Ghalia Indonesia.

Darmawi, Herman. 2011. Manajemen Perbankan. Jakarta: Bumi Aksara.

Kasmir. 2012. Dasar-dasar Perbankan. Edisi Revisi. Jakarta : PT. Raja Grafindo Persada.

Pandia, Frianto. 2012. Manajemen Dana dan Kesehatan Bank. Jakarta: Rineka Cipta Siregar, Sofian. 2010. Statistika Deskriptif Untuk Penelitian. Jakarta : PT. Raja Grafindo Persada. 